8. Ziegler, P. Three Decades of Data Intecration - all Problems Solved? [Text] / P. Ziegler, K. R. Dittrich // Building the Information Society. - Springer US, 2004. - P. 3-12. doi:10.1007/978-1-4020-8157-6 1

9. Weerakkody, V. Integration and Enterprise Architecture Challenges in E-Government [Text] / V. Weerakkody, M. Janssen, K. Hjort-Madsen // International Journal of Cases on Electronic Commerce. - 2007. - Vol. 3, № 2. - P. 13-35. doi:10.4018/jcec.2007040102

10. Dada, D. The Failure of E-Government in Developing Countries: A Literature Review [Electronic resource] / D. Dada / The Electronic Journal of Information Systems in Developing Countries. - 2006. - Vol. 26. - P. 1-10. - Available at: \www/ URL: http://www.ejisdc.org/ojs2./index.php/ejisdc/article/ view $/ 277$

11. Kontogiannis, K. The landscape of service-oriented systems: A research perspective [Text] / K. Kontogiannis, G. A. Lewis, D. B. Smith, M. Litoiu, H. Muller, S. Schuster, E. Stroulia // In Proceedings of the International Workshop on Systems Development in SOA Environments. - IEEE Computer Society, 2007. - P. 1. doi:10.1109/sdsoa.2007.12

12. Sharma, S. K. Web services architecture for m-government issues and challenges [Text] / S. K. Sharma, J. N. D. Gupta // Electronic Government, an International Journal. - 2004. Vol. 1, № 4. - P. 462-474. doi:10.1504/eg.2004.005921

13. Al-Omari, H. E-Government Architecture In Jordan: A Comparative Analysis [Text] / H. Al-Omari // Journal of Computer Science. - 2006. - Vol. 2, № 11. - P. 846-852. doi:10.3844/ jcssp.2006.846.852

14. United Nations Department of Economic and Social Affairs [Electronic resource]. - Available at: \www/URL: https:// www.un.org/development/desa/en/
15. UN E-Government Survey 2014 [Electronic resource]. - Available at: \www/URL: https://publicadministration.un.org/ egovkb/en-us/reports/un-e-government-survey-2014

16. Seebach, P. The Interchange File Format (IFF). Simple, portable, and extensible data storage [Electronic resource] / P. Seebach // IBM. - June 13, 2006. - Available at: \www/URL: https:// www.ibm.com/developerworks/library/pa-spec16/

17. UDDI XML.org web site [Electronic resource]. - Available at: \www/URL: http://uddi.xml.org/

\section{СРАВНЕНИЕ СИСТЕМЫ ЗЛЕКТРОННОГО ПРАВИТЕЛЬСТВА ИОРДАНИИ С СИСТЕМОЙ ЗЛЕКТРОННОГО ЛРАВИТЕЛЬСТВА СОЕДИНЕННЫХ ШТАТОВ}

Данное исследование нацелено на изучение структуры системы электронного правительства в Иордании и ее сопоставления с системой Соединенных Штатов. Исследование показывает, что система электронного правительства в Иордании улучшила предоставление услуг гражданам, поскольку она обеспечивает своевременные, менее дорогостоящие и эффективные услуги. Однако данная система подвержена информационным угрозам и нуждается в постоянном улучшении путем добавления новых технологий и инфраструктуры.

Ключевые слова: архитектура системы электронного правительства, сервисы электронного правительства, система электронного правительство Иордании.

Mohammad Alhawawsha, Postgraduate Student, Departmen of Information Systems, Taras Shevchnko National University of Kyiv, Ukraine, e-mail: mhawawsha@gmail.com, ORCID: http:// orcid.org/0000-0001-5587-3501
Timinsky A.,

Oberemok I.,

Oberemok $\mathbf{N}$.

\title{
DEVELOPMENT OF METHODOLOGY OF EFFICIENCY ESTIMATION OF MANAGEMENT TECHNOLOGY OF PROJECT-ORIENTED ORGANIZATIONS
}

Поставлена задача оцінювання взаємодії проектної і операційної підсистем проектно-орієнтованого підприємства. Визначені суттєві параметри операщійної і проектної підсистем, що розподілені на десять груп параметрів. Запропоновано метод комбінованого аналітично-експертного оцінювання взаємовпливу проектної $і$ операційної підсистем проектно-орієнтованого підприємства. Проаналізовано сильні, слабкі сторони методу, його можливості $i$ загрози.

Ключові слова: проектно-орієнтоване підприємство, операційна підсистема, проектна підсистема, біадаптивне управління, гомеостатичний підхід.

\section{Introduction}

The modern enterprise is compelled to develop constantly for stability maintenance of functioning and profit reception in the conditions of the competitive environment. Development is provided through:

- introduction of new methods, tools, management technologies;

- creation of new products;

- distribution of its activities to other regions and countries.

All such activities are realized through development projects.
Development projects organizationally require other approaches to management, appropriate developing tools in the scientific direction of project and program management.

The joint existence of project management in enterprises and traditional management of operating activities, although it is a requirement of time, gives rise to many problems of consistency between the respective subsystems - project and operating systems.

To solve the problem of coordinated management of project-oriented enterprises, approaches to hybrid, biadaptive, homeostatic management have been developed. However, at the first stage of development of coordina- 
tion approaches with the purpose of efficiency increase of the project-oriented enterprises, it seems necessary: - to highlight the essential parameters of the operating and project subsystems of the project-oriented enterprise;

- to determine an influence of some subsystem parameters on other.

In this article, methodology for implementation of the first step in effectiveness estimation of these enterprises is proposed.

\section{The object of research and its technological audit}

The object of research is a project-oriented enterprise, the management system of which is represented as consisting of two subsystems - the operating management subsystem (management of operating activities) and the project management subsystem (implementation of development projects).

Technological audit of the object reveals significant differences between the project and operating subsystem of the project-oriented enterprise. So, the operating subsystem is aimed at creating the product of the enterprise and its implementation. At the same time, the production cycle of the enterprise does not have clear time limits in its implementation. At the same time, the management system is built, as a rule, according to the functional principle and assumes direct submission of performers. The project subsystem, on the contrary, is oriented to the implementation of enterprise development projects that have clear time limits (the project is a temporary measure to create a unique product or service [1]). In connection with the appearance of the project activity at the enterprise, the phenomenon of double subordination arises [2].

Therefore, the goals and objectives of the project and operating subsystems are different, and the actual scientific and practical task is to ensure their coordinated functioning.

\section{The aim and objectives of research}

The aim of research is to set the task of formulation of the method for estimating the mutual influence of the project and operating subsystems of the project-oriented enterprise and to formulate the corresponding method.

To achieve this aim, it is necessary to perform the following tasks:

1. To determine the initial data for the formulation of a method for estimating the mutual influence of the project and operating subsystems of a project-based enterprise.

2. To formulate the method of expert estimation of the mutual influence of the project and operating subsystems of the project-oriented enterprise.

\section{Research of existing solutions of the problem}

The problems of interaction between the project and operating subsystems of the project-oriented enterprise are studied in the literature. In particular, in the sources of project management and programs, which at the present stage of development are a stable standard all over the world. Thus, in the latest edition of the methodology of the PMBOK (Guide of Project Management Body of Knowledge) [1], in addition to traditional organizational structures, a new composite structure is proposed. In such organizational structure, the interaction between the project and operating subsystems should be implemented most flexibly. In the Japanese standard P2M [3], which proposes a methodology for program management for innovative enterprises, the interaction between the project and operating subsystems is proposed to be harmonized through the mission of the enterprise. The standard of portfolio management [4] emphasizes the difference between operating and project management and provides approaches to building a portfolio management system in project-oriented enterprises.

In the requirements for the competence of project managers [5, 6], a whole class of requirements is identified behavioral ones that take into account knowledge of the specifics of the disagreements between project and operating management and require the integration of the latter.

These approaches are integrated into the field of technologies for managing project-oriented organizations through reengineering projects [7], in which the need for integrated management of the two subsystems is one of the first.

In response to these scientific challenges, the concepts of management of project-oriented organizations were formulated, including the harmonization of the project and operating components:

- the concept of bi-adaptive (mutually adaptive) management [8];

- integrated management through the corporate system [9];

- homeostatic approach [10].

Thus, the results of the literature review allow to conclude that the topic of coordinated management of projectoriented enterprises is promising. But at the same time the subject has a number of problematic areas, consisting, in particular, that the issue of the effectiveness of the interaction between the project and operating subsystems of such enterprises in the literature is not sufficiently explored.

\section{Methods of research}

Let's investigate the influence of the project and operating subsystems on each other, decomposing elements of influence.

Let's use the indices of the following ten spheres of the project and operating subsystems:

F - financial;

E - economic;

M - tangible assets;

$\mathrm{H}$ - HR;

L - logistics;

$\mathrm{T}$ - technologies and technological processes;

B - business processes;

A - advertising activities;

S - plans;

$\mathrm{R}$ - risks and threats.

Let's single out the main parameters that describe the scope of the operating system (Table 1) and the project subsystem (Table 2). The type of parameter estimation in Tables 1,2 have the meaning: $\mathrm{T}$ - the state of the parameter can be estimated accurately, or the E - parameter and its state require an expert estimation. 
The list of essential parameters of the operating subsystem

\begin{tabular}{|c|c|c|c|c|}
\hline № & $\begin{array}{l}\text { Sectors of activity } \\
\text { of the enterprise }\end{array}$ & Parameters of the field & $\begin{array}{c}\text { Type of } \\
\text { estimation }\end{array}$ & $\begin{array}{l}\text { Parameter } \\
\text { designation }\end{array}$ \\
\hline 1 & Financial sectar & $\begin{array}{l}\text { Profit of an enterprise } \\
\text { Wage fund }\end{array}$ & $\begin{array}{l}\mathrm{T} \\
\mathrm{T}\end{array}$ & $\begin{array}{l}f_{1}(1) \\
f_{1}(2)\end{array}$ \\
\hline 2 & Economic sector & $\begin{array}{l}\text { Profitability of the business line } \\
\text { Amount of taxes }\end{array}$ & $\begin{array}{l}\mathrm{T} \\
\mathrm{T}\end{array}$ & $\begin{array}{l}e_{1}(1) \\
e_{1}(2)\end{array}$ \\
\hline 3 & Tangible assets & $\begin{array}{l}\text { Value of tangible assets } \\
\text { Depreciation of tangible assets }\end{array}$ & $\begin{array}{l}\mathrm{T} \\
\mathrm{E}\end{array}$ & $\begin{array}{l}m_{1}(1) \\
m_{1}(2)\end{array}$ \\
\hline 4 & HR sector & $\begin{array}{l}\text { Number of employees } \\
\text { Job satisfaction } \\
\text { Average age of employees }\end{array}$ & $\begin{array}{l}\mathrm{T} \\
\mathrm{E} \\
\mathrm{T}\end{array}$ & $\begin{array}{l}h_{1}(1) \\
h_{1}(2) \\
h_{1}(3)\end{array}$ \\
\hline 5 & Logistics sector & $\begin{array}{l}\text { Number of counterparties } \\
\text { Number of counterparties рег logistic } \\
\text { partner } \\
\text { Number of reserve logistics chains }\end{array}$ & $\begin{array}{l}\mathrm{T} \\
\mathrm{T} \\
\mathrm{T}\end{array}$ & $\begin{array}{l}l_{1}(1) \\
l_{1}(2) \\
l_{1}(3)\end{array}$ \\
\hline 6 & $\begin{array}{l}\text { Technologies and } \\
\text { technological } \\
\text { processes }\end{array}$ & $\begin{array}{l}\text { Number of technologies } \\
\text { Technology effectiveness } \\
\text { Modern technologies } \\
\text { Compatibility of technologies }\end{array}$ & $\begin{array}{l}T \\
E \\
E \\
E\end{array}$ & $\begin{array}{l}t_{1}(1) \\
t_{1}(2) \\
t_{1}(3) \\
t_{1}(4)\end{array}$ \\
\hline 7 & $\begin{array}{l}\text { Business pro- } \\
\text { cesses }\end{array}$ & $\begin{array}{l}\text { Implementation of business processes } \\
\text { Cost of realization of business processes } \\
\text { Profitability of the implementation of } \\
\text { business processes } \\
\text { Consistency of business processes } \\
\end{array}$ & $\begin{array}{l}\mathrm{T} \\
\mathrm{T} \\
\mathrm{E} \\
\mathrm{E}\end{array}$ & $\begin{array}{l}b_{1}(1) \\
b_{1}(2) \\
b_{1}(3) \\
b_{1}(4)\end{array}$ \\
\hline 8 & Marketing sector & $\begin{array}{l}\text { Number of clients of the enterprise } \\
\text { Number of regular customers } \\
\text { Marketing budget for the year } \\
\text { market share }\end{array}$ & $\begin{array}{l}\mathrm{T} \\
\mathrm{T} \\
\mathrm{T} \\
\mathrm{E}\end{array}$ & $\begin{array}{l}a_{1}(1) \\
a_{1}(2) \\
a_{1}(3) \\
a_{1}(4)\end{array}$ \\
\hline 9 & Plans & $\begin{array}{l}\text { Number of business directions } \\
\text { Workforce load } \\
\text { Influence of the project subsystem }\end{array}$ & $\begin{array}{l}\mathrm{T} \\
\mathrm{T} \\
\mathrm{E}\end{array}$ & $\begin{array}{l}s_{1}(1) \\
s_{1}(2) \\
s_{1}(3)\end{array}$ \\
\hline 10 & Risks and threats & $\begin{array}{l}\text { The aggregate value of identified risks } \\
\text { and threats }\end{array}$ & $E$ & $\Gamma_{1}(1)$ \\
\hline
\end{tabular}

The list of essential parameters of the project subsystem

\begin{tabular}{|c|c|c|c|c|}
\hline № & $\begin{array}{l}\text { Sectors of activity } \\
\text { of the enterprise }\end{array}$ & Parameters of the field & $\begin{array}{c}\text { Type of } \\
\text { estimation }\end{array}$ & $\begin{array}{l}\text { Parameter } \\
\text { designation }\end{array}$ \\
\hline 1 & Financial sector & $\begin{array}{l}\text { Project budget } \\
\text { Wage fund } \\
\end{array}$ & $\begin{array}{l}\mathrm{T} \\
\mathrm{T}\end{array}$ & $\begin{array}{l}f_{2}(1) \\
f_{2}(2) \\
\end{array}$ \\
\hline 2 & Economic sector & $\begin{array}{l}\text { Payback time of the project } \\
\text { Amount of taxes }\end{array}$ & $\begin{array}{l}\mathrm{E} \\
\mathrm{T}\end{array}$ & $\begin{array}{l}e_{2}(1) \\
e_{2}(2)\end{array}$ \\
\hline 3 & Tangible assets & $\begin{array}{l}\text { Value of tangible assets } \\
\text { Depreciation of tangible assets }\end{array}$ & $\begin{array}{l}\mathrm{T} \\
\mathrm{E}\end{array}$ & $\begin{array}{l}m_{2}(1) \\
m_{2}(2) \\
\end{array}$ \\
\hline 4 & HR sector & \begin{tabular}{|l} 
Number of employees \\
Job satisfaction \\
Average age of employees \\
\end{tabular} & $\begin{array}{l}\mathrm{T} \\
\mathrm{E} \\
\mathrm{T}\end{array}$ & $\begin{array}{l}h_{2}(1) \\
h_{2}(2) \\
h_{2}(3)\end{array}$ \\
\hline 5 & Logistics sector & $\begin{array}{l}\text { Number of counterparties } \\
\text { Number of counterparties per logistic } \\
\text { partner } \\
\text { Number of reserve logistics chains } \\
\end{array}$ & $\begin{array}{l}\mathrm{T} \\
\mathrm{T} \\
\mathrm{T}\end{array}$ & $\begin{array}{l}l_{2}(1) \\
l_{2}(2) \\
l_{2}(3)\end{array}$ \\
\hline 6 & $\begin{array}{l}\text { Technologies and } \\
\text { technological } \\
\text { processes }\end{array}$ & $\begin{array}{l}\text { Number of technologies } \\
\text { Technology effectiveness } \\
\text { Modern technologies } \\
\text { Compatibility of technologies } \\
\end{array}$ & $\begin{array}{l}\mathrm{T} \\
\mathrm{E} \\
\mathrm{E} \\
\mathrm{E}\end{array}$ & $\begin{array}{l}t_{2}(1) \\
t_{2}(2) \\
t_{2}(3) \\
t_{2}(4) \\
\end{array}$ \\
\hline 7 & $\begin{array}{l}\text { Business pro- } \\
\text { cesses }\end{array}$ & $\begin{array}{l}\text { Implementation of business processes } \\
\text { Cost of realization of business processes } \\
\text { Profitability of the implementation of } \\
\text { business processes } \\
\text { Consistency of business processes } \\
\end{array}$ & $\begin{array}{l}\mathrm{T} \\
\mathrm{T} \\
\mathrm{E} \\
\mathrm{E}\end{array}$ & $\begin{array}{l}b_{2}(1) \\
b_{2}(2) \\
b_{2}(3) \\
b_{2}(4)\end{array}$ \\
\hline 8 & Marketing sector & $\begin{array}{l}\text { Number of potential customers } \\
\text { Marketing budget } \\
\text { Potential market share }\end{array}$ & $\begin{array}{l}\mathrm{E} \\
\mathrm{T} \\
\mathrm{E}\end{array}$ & $\begin{array}{l}a_{2}(1) \\
a_{2}(2) \\
a_{2}(3)\end{array}$ \\
\hline 9 & Plans & \begin{tabular}{|l|} 
Number of projects \\
Workforce load \\
Influence of the operating subsystem \\
\end{tabular} & $\begin{array}{l}\mathrm{T} \\
\mathrm{T} \\
\mathrm{E}\end{array}$ & $\begin{array}{l}s_{2}(1) \\
s_{2}(2) \\
s_{2}(3)\end{array}$ \\
\hline 10 & Risks and threats & $\begin{array}{l}\text { The aggregate value of identified risks } \\
\text { and threats }\end{array}$ & $E$ & $\Gamma_{2}(1)$ \\
\hline
\end{tabular}

Let's formulate the method of combined analytical and expert estimation of the mutual influence of the project and operating subsystems of the project-oriented enterprise (MAEM - method of expert-analytical measurement).

Within the framework of the method, the parameters denoted by the letter $\mathrm{E}$ (Tables 1,2) are supposed to be estimated only with the help of an expert group, parameters denoted by the letter $\mathrm{T}$ - both expertly and analytically.

The main task of the method is to determine the magnitude and modulus of changes of all parameters of the subsystem with respect to the one in which the change occurs.

The list of essential parameters of the project subsystem (Table 2) differs in the content orientation of the parameters concerning the project aspects of the activity. Structurally (and quantitatively) the difference is observed in the financial, economic and marketing sectors.

Let's formulate analytically the main problem of the method of expert-analytical measurement (MAEM) as follows.

The effect of changes in one subsystem (for example, in the operating) on another (for example, project) is described in the example:

$$
\begin{gathered}
V_{2}^{f}(1), V_{2}^{f}(2), V_{2}^{e}(1), \\
V_{2}^{e}(2), V_{2}^{m}(1), V_{2}^{m}(2), \\
V_{2}^{h}(1), V_{2}^{h}(2), V_{2}^{h}(3), \\
V_{2}^{l}(1), V_{2}^{l}(2), V_{2}^{l}(3), \\
V_{1}^{f}(1) \rightarrow V_{2}^{t}(1), V_{2}^{t}(2), V_{2}^{t}(3), \\
V_{2}^{t}(4), V_{2}^{b}(1), V_{2}^{b}(2), \\
V_{2}^{b}(3), V_{2}^{b}(4), V_{2}^{a}(1), \\
V_{2}^{a}(2), V_{2}^{a}(3), V_{2}^{s}(1), \\
V_{2}^{s}(2), V_{2}^{s}(3), V_{2}^{r}(1),
\end{gathered}
$$

The effect of changes in the project subsystem on the operating - by the similar system, where change of each parameters of the project subsystem, $V_{2}^{i}(j), i=[1 . .10]$, $j=[1 . .4]$ causes change of each parameters of the operating subsystem $V_{1}^{i}(j)$, $i=[1 . .10], j=[1 . .4]$.

\section{Research results}

The sequence of MAEM implementation can be represented in the form of eight steps (Fig. 1).

Let's describe the steps of the method.

1. Analytical estimation of the state of T-parameters.

Parameters, the state of which is subject to an accurate, analytical estimation: 
- 18 parameters of the operating subsystem:

$f_{1}(1), f_{1}(2), e_{1}(1), e_{1}(2), m_{1}(1), h_{1}(1)$,

$h_{1}(3), l_{1}(1), l_{1}(2), l_{1}(3), t_{1}(1), b_{1}(1)$,

$b_{1}(2), a_{1}(1), a_{1}(2), a_{1}(3), s_{1}(1), s_{1}(2)$,

the changes of which are reflected respectively:

$$
\begin{aligned}
& V_{1}^{f}(1), \quad V_{1}^{f}(2), \quad V_{1}^{e}(1), \quad V_{1}^{e}(2), \quad V_{1}^{m}(1), \\
& V_{1}^{h}(1), \quad V_{1}^{h}(3), \quad V_{1}^{l}(1), \quad V_{1}^{l}(2), \quad V_{1}^{l}(3) \text {, } \\
& V_{1}^{t}(1), \quad V_{1}^{b}(1), \quad V_{1}^{b}(2), \quad V_{1}^{a}(1), \quad V_{1}^{a}(2), \\
& V_{1}^{a}(3), \quad V_{1}^{s}(1), \quad V_{1}^{s}(2) \text {; }
\end{aligned}
$$

- 15 parameters of the project subsystem:

$f_{2}(1), f_{2}(2), e_{2}(2), m_{2}(1), h_{2}(1), h_{2}(3), l_{2}(1), l_{2}(2)$,

$l_{2}(3), t_{2}(1), b_{2}(1), b_{2}(2), a_{2}(2), s_{2}(1), s_{2}(2)$,

the changes of which are reflected respectively:

$$
\begin{aligned}
& V_{2}^{f}(1), \quad V_{2}^{f}(2), \quad V_{2}^{e}(2), \quad V_{2}^{m}(1), \quad V_{2}^{h}(1), \\
& V_{2}^{h}(3), \quad V_{2}^{l}(1), \quad V_{2}^{l}(2), \quad V_{2}^{l}(3), \quad V_{2}^{t}(1), \\
& V_{2}^{b}(1), \quad V_{2}^{b}(2), \quad V_{2}^{a}(2), \quad V_{2}^{s}(1), \quad V_{2}^{s}(2) \text {. }
\end{aligned}
$$

These parameters can be estimated by the financial and economic division of the organization (in terms of operating components) and the project financial manager (in terms of project components).

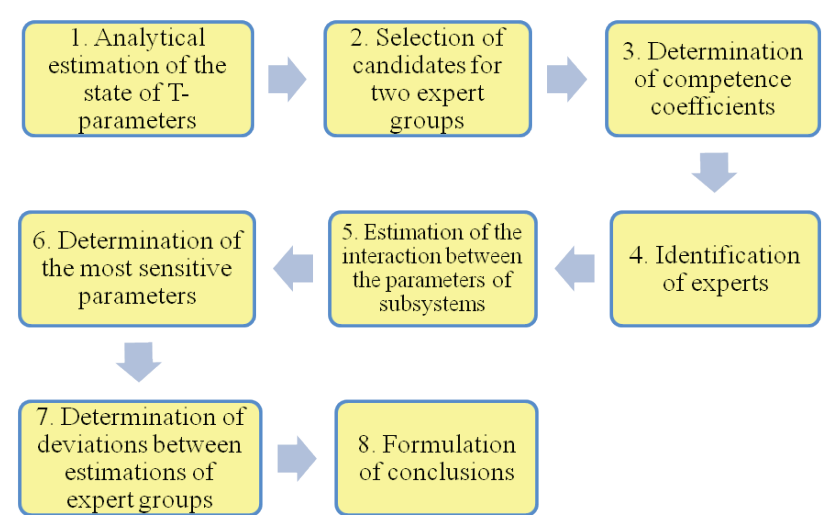

Fig. 1. Steps of MAEM implementation of the mutual influence of the project and operating subsystems of a project-oriented enterprise

2. Selection of candidates for two expert groups.

It is proposed to form two expert groups:

- an expert group of specialists of the operating subsystem of project-oriented enterprises working with projects;

- an expert group of specialists from project offices of project-oriented enterprises, closely cooperated with specialists of the operating subsystem.

The number of participants in each expert group should be between 7 and 15 specialists. To include experts in the number within these limits, a preliminary list of candidates for experts should be analyzed, determining the competence coefficients of each expert.

3. Determination of competence coefficients.

Determination of the competence of experts and, accordingly, the weight of each expert in the expert group is proposed to carry out by calculating the following competency coefficients:
- coefficient of self-esteem $K_{s}$;

- coefficient of cross-valuation $K_{c}$;

- coefficient of professional experience $K_{p}$;

- coefficient obtained from the test task $K_{t}$.

4. Identification of experts.

Based on the results of the preliminary step, the candidates to the expert group receive four estimated coefficients: $K_{s} ; K_{c} ; K_{p} ; K_{t}$, from which the overall competence coefficient $K^{\text {comp }}$ of each $i$-th expert is formed:

$$
K_{i}^{c o m p}=K_{s} \cdot K_{c} \cdot K_{p} \cdot K_{t} .
$$

A certain number of $N^{*}$ (from 7 to 15 ) candidates who received high marks are included in the expert group. Next, calculate the weight $K^{e}$ of each of the experts in the group:

$$
K_{i}^{e}=\frac{K_{i}^{\text {comp }}}{\sum_{i=1}^{N^{*}} K_{i}^{\text {comp }}} .
$$

Thus, the condition $\sum_{i=1}^{N^{*}} K_{i}^{e}=1$ is correct. The two expert groups selected in this way can carry out the next stage of MAEM.

5. Estimation of the interaction between the parameters of the project and operating subsystems

The expert group estimates the impact of each of the 28 parameters of the operating subsystem on each of the 27 parameters of the project subsystem. Further, estimation should be influenced by each of the 27 parameters of the project subsystem for each of the 28 parameters of the operating subsystem.

Definition. Response to an impact is a change of one of the parameters of the bi-adaptive control subsystem (project or operating) under the influence of one of the parameters of the other subsystem (operating or project).

When estimating each response to an impact, estimations of experts in expert groups, in accordance with the theory of peer review, are reclined. Each response to an impact is estimated either as the arithmetic average of the experts' opinions, or (most appropriately) as a weighted average, taking into account the weight of the expert, for example:

$$
\left(V_{2}^{f}(1)\right)^{e g\left(V_{1}^{t}(2)\right)}=\frac{\sum_{i=1}^{N^{*}-2}\left(V_{2}^{f}(1)\right)_{i} \cdot K_{i}^{e}}{N^{*}-2},
$$

where $\left(V_{2}^{f}(1)\right)^{e g\left(V_{1}^{t}(2)\right)}$ - the expert group's estimation of the reaction of the first financial parameter of the project subsystem to the impact of the second technological parameter of the operating subsystem; $N^{*}-2$ - the number of experts, with the exception of two extreme estimations.

Thus, the expert group estimates all reactions to the impact of the operating subsystem:

$$
\left(V_{1}^{k}(d)\right)^{e g\left(V_{2}^{k}(d)\right)},
$$

and all reactions to the effects of the project subsystem:

$$
\left(V_{2}^{k}(d)\right)^{e g\left(V_{1}^{k}(d)\right)},
$$

where $k=[1 . .10]-$ the number of parameter groups, $d=[1 . .4]$ - the number of parameters in the group. 
6. Determination of the most sensitive parameters (changing more compared to other parameters).

The actions that cause the greatest reactions are selected of all the reactions determined by the expert group to the impacts $\left(V_{1}^{k}(d)\right)^{\operatorname{eg}\left(V_{2}^{k}(d)\right)}$ and $\left(V_{2}^{k}(d)\right)^{\operatorname{eg}\left(V_{1}^{k}(d)\right)}$, both from the operating subsystem and from the project subsystem.

7. Determination of deviations between the estimations of two expert groups.

Minimization of errors due to the subjectivity of expert estimations can be carried out by individual methods, for example, by comprehension of the opinions of the participants in the expert group by determining the consistency (concordance) coefficients.

Thus, MAEM gives the following results:

- determination of reactions to the effects of each parameter of the operating subsystem for each parameter of the project subsystem;

- determination of the response to the impact of each parameter of the project subsystem on each parameter of the operating subsystem by the method of expert estimations;

- determination of the impacts that cause the greatest reactions to the parameters of another subsystem, relative to the source of influence.

In addition, the method contains tools to check expert estimations.

\section{SWOT analysis of research results}

Strengths. The strengths of the proposed method include: - the possibility of obtaining an estimation of the impact of the project subsystem on the operating subsystem and vice versa for further research on models of coordinated management of the project-oriented enterprise within the framework of the building of hybrid, bi-adaptive or homeostatic management;

- checking of expert opinions by methods predicted by the theory of expert estimations - rejection of extreme estimations, calculation of the concordance coefficients, etc.;

- the method will ensure the optimization of the management system of project-oriented organizations and increase their productivity.

Weaknesses. The weaknesses of the proposed method include:

- subjectivity of experts in estimation of the mutual influence parameters of the project and operating subsystems, and although expert estimations are processed to minimize it, but subjectivity is embedded in the very essence of the expert method;

- not all described parameters are included in the proposed list of operating and project subsystem parameters;

- the method increases the labor forces for its implementation.

Opportunities. Proposed MAEM allows:

- to determine the essential parameters of the operating subsystem, most affect the project subsystem, and the essential parameters of the project subsystem, most affect the operating system;

- to build conceptual models of hybrid, bi-adaptive or homeostatic management of project-oriented organizations; - method will increase the flexibility of the management system and accelerate the speed of decision-making in the case of its implementation at a project-based enterprise.

Threats. The expert estimation approach, which is the MAEM basis, is laborious and requires a lot of time for implementation.

\section{Conclusions}

1. The task to determine the mutual influence of project and operating subsystem of project-oriented enterprises is set. The parameters of the project and operation subsystems are divided into 10 spheres - financial, economic, tangible assets, HR, logistics, technology and technological processes, business processes, advertising activities, plans, risks and threats. 28 essential parameters of the operating subsystem and 27 essential parameters of the project subsystem are determined.

2. The method of combined analytical and expert estimation of the interaction between the project and operating subsystems of the project-oriented enterprise (MAEM) is proposed. MAEM is based on the method of peer review. Eight steps of method implementation are formulated and described. The developed method will allow the projectoriented enterprises to increase the efficiency, flexibility and efficiency of the management system.

MAEM will determine the magnitude of the mutual influence between the project and operating subsystems of the project-oriented enterprises. This will offer them models of management based on hybrid, bi-adaptive or homeostatic approaches.

\section{References}

1. A Guide to the Project Management Body of Knowledge (PMBOK ${ }^{\circledR}$ Guide) [Text]. - Ed. 5. - Project Management Institute, 2013. - $590 \mathrm{p}$

2. Kerzner, H. Project Management: A Systems Approach to Planning, Scheduling, and Controlling [Text] / H. Kerzner. Ed. 10. - USA, New Jersey: Wiley, 2009. - 1120 p.

3. $\mathrm{P} 2 \mathrm{M}$ «Program \& Project Management for Enterprise Innovation» [Electronic resource]. - Project Management Association of Japan, 2016. - Available at: \www/URL: http://www.pmaj. or.jp/ENG/p2m/p2m guide/p2m guide.html

4. The Standard for Portfolio Management [Text]. - Ed. 3. Project Management Institute, 2013. - 189 p.

5. ICB: IPMA Competence Baseline Version 3.0 [Text]. - IPMA, Netherlands, 2006. - 200 p.

6. ISO 21500:2012. Guidance on project management [Text]. Project Committee ISO/PC 236, 2012. - 36 p.

7. Champy, J. X-Engineering the Corporation : Reinventing Your Business in the Digital Age (Hardcover) [Text] / J. Champy. New York: Warner Business Books, 2002. - 232 p.

8. Teslya, Yu. Analysis of approaches to constructing bi-adaptive management systems of project-oriented enterprises [Text] Yu. Teslya, A. Timinsky // Eastern-European Journal of Enterprise Technologies. - 2015. - № 2/3 (74). - P. 38-42. doi:10.15587/1729-4061.2015.39988

9. Oberemok, I. Flexible approach to the implementation of corporate project management system [Text] / I. Oberemok // Management of Development of Complex Systems. - 2014. № 17 . - P. 42-45.

10. Oberemok, I. Homeostatic approach to project management [Text] / I. Oberemok // Management of Development of Complex Systems. - 2014. - № 19. - P. 50-53.

\section{РАЗРАБОТКА МЕТОДИКИ ОЦЕНКИ ЗФФЕКТИВНОСТИ} ТЕХНОЛОГИЙ УПРАВЛЕНИЯ ПРОЕКТНО-ОРИЕНТИРОВАННЫМИ ОРГАНИЗАЦИЯМИ

Поставлена задача оценивания взаимодействия проектной и операционной подсистем проектно-ориентированного пред- 
приятия. Определены существенные параметры операционной и проектной подсистем, разделенные на десять групп параметров. Предложен метод комбинированной аналитически-экспертной оценки взаимовлияния проектной и операционной подсистем проектно-ориентированного предприятия. Проанализированы сильные, слабые стороны метода, его возможности и угрозы.

Ключевые слова: проектно-ориентированное предприятие, операционная подсистема, проектная подсистема, биадаптивное управление, гомеостатический подход.

Timinsky Alexander, PhD, Associate Professor, Department of Management Technologies, Taras Shevchenko National University of Kyiv, Ukraine, e-mail: timin@ukr.net, ORCID: http://orcid.org/ 0000-0001-8265-6932

Oberemok Ivan, PhD, Associate Professor, Department of Project Management, Kyiv National University of Construction and Architecture, Ukraine, e-mail: oberemokii@gmail.com, ORCID: http:// orcid.org/0000-0002-9194-0852

Oberemok Nataliia, PhD, Associate Professor, Department of Geoinformatics, Taras Shevchenko National University of Kyiv, Ukraine, e-mail: oberemokn@gmail.com, ORCID: http://orcid.org/0000-00027230-8149 